\title{
Meningkatkan Keterampilan Menulis Surat Pribadi dengan Menggunakan Model Examples Non Examples pada Siswa Kelas VII A SMP Negeri 9 Kota Sorong Tahun pelajaran 2016/2017
}

\author{
Alice Fransisca Soplanit \\ SMP Negeri 9 Kota Sorong \\ email: alicesoplanit@gmail.com
}

\begin{abstract}
Abstrak: Pembelajaran menulis surat pribadi memiliki permasalahan, karena selain melibatkan kemampuan siswa dalam menulis, siswa dituntut untuk mampu berekspresi dan kritis yang diwujudkan dalam sebuah tulisan. Penelitian ini adalah penelitian tindakan kelas (Classroom Action and Research) yang bertujuan untuk meningkatkan keterampilan menulis surat pribadi dengan menggunakan model pembelajaran Examples Non Examples pada siswa kelas VII A SMP Negeri 9 Kota Sorong tahun pelajaran 2016/2017. Subyek penelitian adalah siswa kelas VII A yang terdiri atas 32 siswa yang terdiri atas 10 lakilaki dan 22 perempuan dengan karakter siswa yang beragam, baik prestasi belajar, maupun kemampuan menulis mereka. Pengambilan data dilakukan dengan menggunakan tes dan non tes (Observasi dan wawancara). Data yang terkumpul dianalisis dengan menggunakan analisis kualitatif dan kuantitatif. Hasil penelitian disimpulkan bahwa: 1). Teknik pengamatan objek secara langsung, kemampuan siswa kelas VII A SMP Negeri 9 Kota Sorong dalam menulis surat pribadi dapat ditingkatkan. Hal ini terbukti pada hasil tes setelah tindakan. Pada tahap pratindakan nilai rata-rata siswa hanya 48,75\% atau kategori kurang, kemudian pada tindakan siklus I nilai rata-rata yang diperoleh 82,75 \% atau kategori baik, artinya mengalami peningkatkan sebesar $81,22 \%$ Kemudian pada siklus II nilai rata-rata siswa meningkat lebih baik lagi daripada siklus I, yaitu menjadi 97,69 \%, Dengan kata lain mengalami peningkatan sebesar 95,10 $\%$ bila dibandingkan dengan hasil sebelumnya. Hasil penelitian non tes melalui pengamatan, wawancara, dan jurnal siswa juga menunjukkan perubahan yang positif, siswa lebih tertarik dan antusias dalam pembelajaran menulis dengan menggunakan metode examples non examples, sehingga siswa mudah dalam menulis surat pribadi.
\end{abstract}

Kata Kunci : keterampilan menulis,,examples non examples, surat pribadi

\begin{abstract}
The type of this research is classroom action research (Research) which is carried out collaboratively between researchers and teachers. This study aims to determine the increase in the Main Mathematics Learning Outcomes of the Volume of cubes and beams for Class V Students at SD Inpres 33 of Sorong Regency through a Contextual Approach. The subjects of the study were all fifth grade students in the Odd Semester 2017/2018 Academic Year with as many as 30 students, consisting of 14 men and 16 women. In its implementation consisting of 2 cycles, namely Cycle I was held for four meetings and Cycle II was held for four meetings. Data retrieval is done by using Cycle and Observation Final Tests.. The collected data was analyzed using qualitative and quantitative analysis. Grade V mathematics learning outcomes in the 2017/2018 Odd Semester Academic Year increased after learning with a contextual approach for two cycles with the following results: (1) Student mathematics learning outcomes before learning with contextual approaches are in the low category with an average value 50.66 from the highest score of 70 and the lowest value 20. (2) The results of student mathematics learning after Cycle I learning with a contextual approach with an average value of 58.66 from the highest value of 80 and the lowest value 40. (3). The mathematics learning outcomes of students after learning with the Cycle II contextual approach are in the moderate category with an average value of 68.67 from the highest score of 100 and the lowest value of 50. (4) There is an increase in the presence of teaching and learning activities, and (5) An increase students' mathematics learning motivation.
\end{abstract}

Keywords: mathematics learning outcomes, contextual approach, and volume of cubes and beams 


\section{Pendahuluan}

Surat sebagai alat komunikasi yang menggunakan bahasa tulisan di atas selembar kertas, pada era modern ini mengalami kemajuan. Adanya alat canggih seperti komputer dan telepon genggam sangat mempengaruhi cara berkomunikasi siswa. Walaupun begitu penguasaan gaya bahasa kalimat, dan pola pengembangan paragraf masih sangat dibutuhkan dengan ide, gagasan dan perasaan dapat dipahami oleh pembaca. Berkomunikasi dengan surat pribadi harus dapat ditingkatkan oleh peserta didik supaya keterampilan menulis semakin meningkat.

Proses pembelajaran bahasa Indonesia di SMP Negeri 9 Kota Sorong masih belum cukup memuaskan. Nilai rata-rata pada aspek masih di bawah standar yang telah ditentukan pada awal semester. Hal ini menuntut guru untuk melakukan remidial, akan tetapi, terkadang pelaksanaan remedial bersifat hanya formalitas saja. Remedial tidak dilakukan dengan sebenarnya. Remedial hanya dilakukan sebagai sebuah proses mengangkat nilai anak dari kondisi di bawah ketuntasan minimal menjadi kondisi mencapai ketuntasan minimal.

Menurut Tarigan (1988:3) dalam "Teknik Pengajaran Keterampilan Berbahasa” dijelaskan bahwa keterampilan menulis walaupun sering berada pada posisi terakhir dalam urutan keterampilan berbahasa, mendapat posisi paling penting dalam kehidupan ilmiah seseorang. Oleh karena itu, seseorang dapat dikatakan sebagai akademisi yang baik jika ia telah teruji kemampuan menulisnya. Dalam pembelajaran bahasa Indonesia, tentunya pembelajaran menulis mengambil peranan yang sangat penting. Hal ini terjadi karena semua materi pelajaran akan dapat dipahami dengan membaca. Tidak seperti membaca dan menyimak, sama halnya dengan keterampilan berbicara, keterampilan menulis membutuhkan proses khusus agar menjadi lebih terampil. Proses khusus inilah yang disebut dengan berlatih terus-menerus. Proses berlatih terus-menerus ini adalah sebuah proses pembiasaan yang sebaiknya dilakukan seseorang sejak usia dini. Penelitian ini mencoba menawarkan sebuah terapi menulis sejak usia dini. Dalam penelitian ini, penulis berusaha menerapi siswa kelas VII A agar memiliki kecintaan terhadap dunia tulis-menulis melalui media surat, dengan berlatih secara intensif menulis surat, akhirnya secara tidak sadar, siswa telah berlatih menjadi seorang penulis. Tidak seperti membaca dan menyimak, sama halnya dengan keterampilan berbicara, keterampilan menulis membutuhkan proses khusus agar menjadi lebih terampil. Proses khusus inilah yang disebut dengan berlatih terus-menerus. Proses berlatih terus-menerus ini adalah sebuah proses pembiasaan yang sebaiknya dilakukan seseorang sejak usia dini. Penelitin ini mencoba menawarkan sebuah terapi menulis sejak usia dini. Dalam penelitian ini, penulis menerapi siswa kelas VII A agar memiliki kecintaan terhadap dunia tulis-menulis melalui media surat. Dengan berlatih secara intensif menulis surat, akhirnya secara tidak sadar, siswa telah berlatih menjadi seorang penulis.

Ada beberapa faktor yang menyebabkan pembelajaran menulis surat pribadi tidak berjalan dengan baik, yaitu antara lain ; 1). Penjelasan dari guru kurang detail, sehingga membatasi ruang lingkup pikiran siswa terhadap surat pribadi, 2). Minat baca siswa yang kurang begitu antusias terhadap materi pembelajaran surat pribadi, 3). Siswa tidak terbiasa dalam menulis surat pribadi, 4). Siswa sulit merangkai kata/kalimat dalam membuat surat pribadi, 5). Metode yang digunakan guru kurang cocok, sehingga materi tidak tersampaikan dengan baik, dan 6). Kurangnya sarana dan prasarana yang mendukung pembelajaran surat pribadi.

Dari hal-hal tersebut di atas dapat ditarik kesimpulan bahwa permasalahan dalam materi pembelajaran menulis surat pribadi merupakan suatu masalah yang kompleks. Karena selain melibatkan kemampuan siswa dalam menulis, siswa juga dituntut untuk mampu berekspresi dan kritis yang diwujudkan dalam sebuah tulisan.

Keterampilan menulis di sekolah merupakan kegiatan yang bertujuan untuk meningkatkan keterampilan menulis siswa. Salah satu keterampilan yang diajarkan adalah menulis surat pribadi. 
Menulis surat pribadi merupakan kegiatan menulis yang dimaksudkan untuk bisa melakukan komunikasi secara tertulis dengan komposisi, isi, dan bahasa yang benar. Berdasarkan hasil refleksi awal oleh penulis diperoleh data bahwa minat dan kemampuan siswa dalam menulis masih rendah. Pernyataan ini didukung dengan data-data sebagai berikut. 1). Ketuntasan belajar pada aspek menulis yang diperoleh siswa rata-rata hanya 50\% dari jumlah siswa; 2). Siswa tidak tertarik dengan tugas-tugas yang sifatnya menulis; 3). Referensi dalam keterampilan menulis yang disediakan sekolah sangat minim; dan 4) Kurangnya pengetahuan siswa tentang menulis.

Menulis bukanlah perkara mudah bagi seorang siswa, apalagi menulis surat pribadi membutuhkan pemikiran yang lumayan lama juga, untuk merangkai kata demi kata sesuai dengan komposisi, isi dan bahasa. Apalagi dalam pembelajaran di kelas, tidak mungkin dalam waktu dua jam pelajaran siswa mampu untuk menulis sebuah surat pribadi. Hal inilah yang mendorong penulis untuk melakukan penelitian tindakan dalam pembelajaran menulis ini dengan menggunakan model Examples Non Examples, dengan judul Meningkatkan Keterampilan menulis surat pribadi dengan menggunakan model Examples Non Examples pada siswa kelas VII A SMP Negeri 9 Kota Sorong tahun pelajaran 2016/2017.

Dalam model ini, pengajar akan memperlihatkan contoh dari sebuah surat pribadi, juga komposisi, isi dan bahasa yang dipakai. Kemudian masing-masing kelompok mendiskusikan dengan kelompoknya untuk membuat sebuah surat pribadi sesuai dengan topik yag diberikan oleh guru. Setelah semua terselesaikan, kemudian pengajar menyuruh salah satu kelompok untuk mempresentasikan hasil pekerjaannya. Dalam proses ini siswa dalam kelompok lain diharapkan bertanya untuk mendapatkan kejelasan penulisan surat pribadi yang dipresentasikan oleh kelompok yang maju ke depan. Di saat itulah pengajar akan mengetahui hasil dari pekerjaan siswa, sesuai dengan contoh-contoh yang sudah dijelaskan pengajar sebelumnya. Bila semua kelompok sudah mengerjakan tugasnya, kemudian setelah itu giliran semua siswa diberi tugas untuk menuliskan sebuah surat pribadi sesuai dengan topik-topik yang sudah diberikan oleh guru. Tugas tersebut bertujuan untuk mengukur sampai sejauh mana kemampuan tiap-tiap siswa dalam membuat sebuah surat pribadi.

Penelitian tindakan kelas ini mempunyai indikator keberhasilan untuk dijadikan landasan yaitu: Penelitian dianggap berhasil apabila $75 \%$ dari jumlah siswa memperoleh nilai minimal atau sama dengan 75. Apabila hasil penelitian tidak memenuhi indikator keberhasilan, maka pada siklus berikutnya akan diperbaiki kelemahan-kelemahan pada siklus I. Apabila hasil penelitian memenuhi indikator keberhasilan maka pada siklus berikutnya atau pada siklus II, kriteria keberhasilan penelitian akan ditinggikan.

Berangkat dari permasalahan tersebut, penulis terdorong untuk melakukan Penelitian Tindakan Kelas (PTK) dengan judul "Meningkatkan Keterampilan Menulis Surat Pribadi menggunakan Model Examples Non Examples pada Siswa Kelas VII A SMP Negeri 9 Kota Sorong Tahun Pelajaran 2016/2017'.

\section{Metode Penelitian}

Penelitian ini menggunakan desain PTK yaitu penelitian tindakan kelas. Yang dimaksud dengan penelitian tindakan kelas adalah penelitian yang dilakukan di kelas untuk menyelesaikan permasalahan agar pembelajaran dapat berhasil dan berjalan dengan baik. Penelitian tindakan kelas ini berisi pratindakan dan tindak lanjut.

Skenario tindakan pembelajaran yang digunakan dalam penelitian tindakan kelas ini diambil dari model PTK menurut Kemmis and McTaggart (1990:14). Model ini berupa untaianuntaian dengan satu perangkat yang terdiri dari empat komponen, yaitu perencanaan (planning), tindakan (acting), observasi (observing), dan refleksi (reflecting). Untaian yang terdiri dari empat 
komponen ini disebut sebagai satu siklus. Pada penelitian ini, dirancang dan dilaksanakan dua siklus. Setiap siklus terdiri dari satu pertemuan dengan masing-masing pertemuan terdiri dari 8 tahap kegiatan pada siklus I, dan 7 tahap kegiatan pada siklus II, dengan menggunakan model Examples Non Examples. Setiap siklus bertujuan untuk menilai kemampuan menulis surat pribadi dengan rincian, pada pertemuan pertama/siklus I menilai kemampuan siswa untuk indikator mampu menentukan perbedaan komposisi, isi dan bahasa serta menulis surat pribadi dengan bahasa yang komunikatif, sedangkan pada pertemuan kedua/siklus II menilai kemampuan untuk indikator yang sama pada siklus I, namun di siklus II harus ada peningkatan daripada siklus I.

Penelitian Tindakan Kelas ini dilakukan pada siswa kelas VII A SMP Negeri 9 Kota Sorong tahun pelajaran 2016/2017. Kelas ini terdiri atas 32 siswa yang terdiri atas 10 laki-laki dan 22 perempuan dengan karakter siswa yang beragam, baik prestasi belajar, maupun kemampuan menulis mereka. Penelitian ini dilaksanakan pada bulan Oktober sampai dengan November 2016. Pemilihan setting ini didasari oleh hasil refleksi awal yang dilakukan peneliti yang bernama SMP Negeri 9 Kota Sorong di kelas VII A bersama guru bahasa Indonesia yang bernama Ibu Nurhayati, S.Pd. sebagai kolaborator di sekolah tersebut. Dalam pengidentifikasian masalah tersebut ditemukan bahwa kompetensi menulis surat pribadi dengan memperhatikan komposisi, isi, dan bahasa, dimana kelas VII A sangat kurang dalam minat dan hasil belajar menulis yang cukup rendah.

Untuk mendapatkan data, peneliti menggunakan instrumen tes dan instumen non tes. Pada instrumen tes ini, dilakukan oleh peneliti dan ada dua siklus yaitu siklus I dan siklus II, dengan tujuan untuk mengukur hasil kemampuan menulis surat pribadi. Oleh sebab itu siswa disuruh untuk menulis surat pribadi sesuai dengan topik yang sudah ditentukan oleh guru. Hasil tes pada siklus pertama dianalisis, dinilai, kemudian peneliti mencari kesulitan-kesulitan yang dialami siswa atau kelemahan-kelemahan siswa dalam hal menulis surat pribadi. Pada pertemuan berikutnya siswa diberi teknik-teknik atau cara menulis surat pribadi dengan mudah. Sampai siswa dapat menulis surat pribadi dengan tepat sesuai dengan topik yang sudah ditentukan oleh guru, dan diberi tes lagi pada siklus berikutnya.

Hasil tes pada siklus kedua diharapkan siswa mendapatkan hasil yang lebih baik. Untuk memberikan penilaian terhadap hasil tes penulis menggunakan skor. Adapun skor penilaian pada instrumen dapat dilihat pada tabel berikut ini:

Tabel 1. Kriteria penilaian tiap aspek dalam menulis surat pribadi

\begin{tabular}{cll}
\hline No & \multicolumn{1}{c}{ Aspek yang dinilai } & \multicolumn{1}{c}{ Rentang Skor } \\
\hline 1 & Komposisi surat & Komposisi lengkap $=10$ \\
& & Komposisi hanya ada 5-7 =8 \\
& & Komposisi hanya ada $2-4=6$ \\
& & Komposisi hanya ada $1=2$ \\
2 & \multirow{2}{*}{ Bahasa surat } & Bahasa komunikatif $=10$ \\
& & Kurang komunikatif $=5$ \\
3 & \multirow{2}{*}{ Isi surat } & Tidak komunikatif $=2$ \\
& & Isi sesuai dengan topik $=10$ \\
& & Kurang sesuai dengan topik $=5$ \\
& & Tidak sesuai dengan topik $=2$ \\
\hline
\end{tabular}

Intrumen non tes yang digunakan peneliti adalah observasi dan wawancara. Pada observasi atau pengamatan yang dilakukan guru dengan tujuan untuk mengetahui keaktifan siswa dalam pembelajaran menulis surat pribadi dan respon siswa terhadap pembelajaran tersebut. Adapun aspek yang diamati meliputi: (1). Tingkat keaktifan siswa ketika mengikuti pembelajaran menulis 
surat pribadi, (2). Respon siswa dalam menerima materi pembelajaran menulis surat pribadi, dan (3). Respon siswa terhadap pembelajaran dengan menggunakan metode examples non examples. Wawancara bertujuan untuk mendapatkan informasi dari siswa bagaimana tentang pembelajaran menulis surat pribadi tentang kesulitan-kesulitan yang dihadapi siswa. Setelah mengetahui kesulitan-kesulitan yang dihadapi siswa, kemudian peneliti berusaha menerapkan examples non examples.

Teknik analisis data yang digunakan peneliti adalah teknik kuantitatif dan teknik kualitatif. Pada teknik kuantitatif, peneliti menganalisis hasil kuantitatif dari siswa. Adapun yang diperoleh dari peneliti kemudian dikoreksi dengan memberikan nilai. Setelah itu nilai direkap keseluruhannya, untuk dihitung nilai rata-rata. Teknik kualitatif digunakan untuk menganalisis teknik yang berasal dari non tes yaitu observasi atau pengamatan, jurnal dan wawancara terhadap siswa. Yang bertujuan untuk mengetahui perubahan-perubahan dan perilaku siswa setelah diberikan tindakan pada siklus I dan siklus II.

\section{Hasil dan Pembahasan}

\subsection{Hasil Penelitian}

Hasil penelitian tindakan kelas pada menulis surat pribadi dengan menggunakan metode example non example, diperoleh dari hasil tes dan non tes, dan terdiri dari siklus I dan siklus II. Pada tes pratindakan ini hasilnya diperoleh dari rata-rata nilai menulis surat pribadi sebelum diterapkan teknik pengamatan objek secara langsung. Selanjutnya dari hasil pratindakan digunakan untuk menyusun rancangan pembelajaran pada tahap siklus I. selanjutnya hasil penilaian atau evaluasi pembelajaran pada tahap siklus I disempurnakan pada rancangan pembelajaran siklus II.

Hasil tes pratindakan adalah hasil proses pembelajaran menulis surat pribadi yang belum disertai tindakan pembelajaran dengan menggunakan metode examples non examples. Hasil tes pratindakan ini dilakukan untuk mengetahui kemampuan awal siswa dalam menulis surat pribadi. Hasil tes pratindakan dapat dilihat pada tabel berikut :

\section{Tabel 2. Hasil Tes Aspek Komposisi Surat}

\begin{tabular}{ccccccc}
\hline No & Kategori & $\begin{array}{c}\text { Rentang } \\
\text { Nilai }\end{array}$ & $\begin{array}{c}\text { Jml } \\
\text { Siswa }\end{array}$ & Skor & Persen & Rata-rata \\
\hline 1 & Sangat Baik & $86-100$ & 0 & 0 & 0 & $\underline{1866}$ \\
2 & Baik & $81-85$ & 5 & 385 & $15,65 \%$ & 32 \\
3 & Cukup & $75-80$ & 13 & 838 & $40,69 \%$ & $=58,32 \%$ \\
4 & Kurang & $0-74$ & 14 & 643 & $43,82 \%$ & \\
\hline
\end{tabular}

Dari tabel 2 dapat dilihat bahwa nilai rata-rata kelas dalam aspek kelengkapan komposisi surat adalah 58,32 \% atau kategori kurang. Dari keseluruhan siswa yang mendapat skor $86-100$ atau kategori baik sekali belum ada, Kategori baik dengan rentang nilai 81 - 85 ada 5 siswa atau $15,65 \%$, kategori cukup dengan rentang nilai 75 - 80 siswa ada 13 siswa atau 40,69\%, dan kategori kurang dengan rentang nilai 0 - 74 ada 14 siswa atau 43,82\%.

\section{Tabel 3. Hasil Tes Aspek Isi Surat}

\begin{tabular}{ccccccc}
\hline No & Kategori & $\begin{array}{c}\text { Rentang } \\
\text { Nilai }\end{array}$ & $\begin{array}{c}\text { Jml } \\
\text { Siswa }\end{array}$ & Skor & Persen & Rata-rata \\
\hline 1 & Sangat Baik & $86-100$ & 0 & 0 & 0 & $\underline{1797}$ \\
2 & Baik & $81-85$ & 5 & 160 & $15,65 \%$ & 32 \\
3 & Cukup & $75-80$ & 14 & 922 & $43,82 \%$ & $=56,16 \%$ \\
4 & Kurang & $0-74$ & 13 & 715 & $40,69 \%$ & \\
\hline
\end{tabular}


Dari tabel 3 dapat dilihat bahwa nilai rata-rata kelas dalam aspek kesesuaian isi surat dengan topik adalah 56,16 \% atau kategori kurang. Dari keseluruhan siswa yang mendapat skor 86 - 100 atau kategori baik sekali belum ada, Kategori baik dengan rentang nilai $81-84$ ada 5 siswa atau $15,65 \%$ kategori cukup dengan rentang nilai $75-80$ ada 14 siswa atau 53,82\% dan kategori kurang dengan rentang nilai 0 - 74 ada 13 siswa atau 40,69\%.

Tabel 4. Hasil Tes Aspek Bahasa Surat

\begin{tabular}{ccccccc}
\hline No & Kategori & $\begin{array}{c}\text { Rentang } \\
\text { Nilai }\end{array}$ & $\begin{array}{c}\text { Jml } \\
\text { Siswa }\end{array}$ & Skor & Persen & Rata-rata \\
\hline 1 & Sangat Baik & $86-100$ & 0 & 0 & 0 & $\underline{1420}$ \\
2 & Baik & $81-85$ & 3 & 240 & $9,39 \%$ & 32 \\
3 & Cukup & $75-80$ & 15 & 1080 & $46,95 \%$ & $=44,38 \%$ \\
4 & Kurang & $0-74$ & 14 & 100 & $43,82 \%$ & \\
& & 32 & 1420 & & \\
\hline
\end{tabular}

Dari tabel 4 dapat dilihat bahwa nilai rata-rata kelas dalam aspek penggunaan bahasa dalam surat adalah 44,38 \% atau kategori cukup. Dari keseluruhan siswa yang mendapat skor 86 - 100 atau kategori baik sekali belum ada, Kategori baik dengan rentang nilai 81 - 85 ada 3 siswa atau 9,39 $\%$ kategori cukup dengan rentang nilai 75 - 80 ada 15 siswa atau 46,95\% dan kategori kurang dengan rentang nilai $0-74$ ada 14 siswa atau 43, $82 \%$.

Tabel 5. Hasil Tes Pratindakan

\begin{tabular}{ccccccc}
\hline No & Kategori & $\begin{array}{c}\text { Rentang } \\
\text { Nilai }\end{array}$ & $\begin{array}{c}\text { Jml } \\
\text { Siswa }\end{array}$ & Skor & Persen & Rata-rata \\
\hline 1 & Sangat Baik & $86-100$ & 0 & 0 & 0 & $\underline{1560}$ \\
2 & Baik & $81-85$ & 5 & 240 & $15,65 \%$ & 32 \\
3 & Cukup & $75-80$ & 16 & 1120 & $50,08 \%$ & $=48,75 \%$ \\
4 & Kurang & $0-74$ & 11 & 200 & $34,43 \%$ & \\
& & 32 & 1560 & & \\
\hline
\end{tabular}

Dari tabel 5 hasil tes keterampilan menulis puisi pratindakan tampak bahwa kemampuan menulis kreatif puisi siswa kelas VII A SMP Negeri 9 Kota Sorong masih rendah terbukti bahwa rata-rata nilai menulis surat pribadi siswa hanya 48,75\% atau kategori kurang. Adapun rincian data tersebut dijelaskan sebagai berikut. Dari jumlah keseluruhan 32 siswa, 11 siswa atau 15,65\% termasuk dalam kategori kurang dengan skor $0-74$. Kategori cukup dengan skor $75-80$ dicapai oleh siswa sebanyak 16 siswa atau 50,08 \%, kategori baik dengan skor $80-85$ dicapai oleh 5 siswa atau 15, 65\%, sedangkan siswa yang mencapai kategori sangat baik atau dengan skor $86-$ 100 belum ada. Dengan demikian dapat disimpulkan bahwa kemampuan menulis surat pribadi siswa kelas VII A SMP Negeri 9 Kota Sorong masih rendah. Rendahnya keterampilan siswa dalam menulis surat pribadi ini disebabkan karena faktor internal yaitu dari siswa sendiri dan faktor eksternal diantaranya metode pembelajaran yang digunakan kurang sesuai. Tahap siklus I merupakan tindak lanjut awal dalam menyelesaikan masalah yaitu rendahnya menulis surat pribadi pada kelas VII A SMP Negeri 9 Kota Sorong.

Tabel 6. Hasil Tes Aspek Komposisi Surat

\begin{tabular}{ccccccc}
\hline No & Kategori & $\begin{array}{c}\text { Rentang } \\
\text { Nilai }\end{array}$ & $\begin{array}{c}\text { Jml } \\
\text { Siswa }\end{array}$ & Skor & Persen & Rata-rata \\
\hline 1 & Sangat Baik & $86-100$ & 4 & 380 & $12,52 \%$ & $\underline{2589}$ \\
2 & Baik & $81-85$ & 13 & 1093 & $40,69 \%$ & 32 \\
3 & Cukup & $75-80$ & 11 & 880 & $34,43 \%$ & $=80,91 \%$ \\
\hline
\end{tabular}




\begin{tabular}{llcccc}
\hline 4 & Kurang & $0-74$ & 4 & 236 & $12,52 \%$ \\
\hline & & 32 & 2589 & \\
\hline
\end{tabular}

Dari tabel 6 dapat dilihat bahwa nilai rata-rata kelas dalam aspek kelengkapan komposisi surat adalah 80,91\% atau kategori baik. Dari keseluruhan siswa yang mendapat skor $86-100$ atau kategori baik sekali ada 4 siswa atau 12,52\%, Kategori baik dengan rentang nilai 81 - 85 ada 13 siswa atau 40,69 \%, kategori cukup dengan rentang nilai 75 - 80 ada 11 siswa atau 34,43\%, dan masih terdapat kategori kurang dengan rentang nilai 0 - 74 sebanyak 4 siswa atau 12,52\%.

\section{Tabel 7. Hasil Tes Aspek Isi Surat}

\begin{tabular}{ccccccc}
\hline No & Kategori & $\begin{array}{c}\text { Rentang } \\
\text { Nilai }\end{array}$ & $\begin{array}{c}\text { Jml } \\
\text { Siswa }\end{array}$ & Skor & Persen & Rata-rata \\
\hline 1 & Sangat Baik & $86-100$ & 3 & 294 & $9,39 \%$ & $\underline{2642}$ \\
2 & Baik & $81-85$ & 14 & 1190 & $43,82 \%$ & 32 \\
3 & Cukup & $75-80$ & 13 & 1040 & $40,69 \%$ & $=82,57 \%$ \\
4 & Kurang & $0-74$ & 2 & 118 & $6,26 \%$ & \\
\hline & & 32 & 2642 & & \\
\hline
\end{tabular}

Dari tabel 7 dapat dilihat bahwa nilai rata-rata kelas dalam aspek kesesuaian isi surat dengan topik adalah 82,57 \% atau kategori baik. Dari keseluruhan siswa yang mendapat skor $86-100$ atau kategori sangat baik sekali ada 3 siswa atau 9,39\%, Kategori baik dengan rentang nilai 81 85 ada 14 siswa atau $43,82 \%$, kategori cukup dengan rentang nilai 75 - 80 ada 13 siswa atau $40,69 \%$, dan masih terdapat 2 orang siswa atau 6,26 \% dalam kategori kurang dengan rentang nilai $0-74$.

Tabel 8. Hasil Tes Aspek Bahasa Surat

\begin{tabular}{ccccccc}
\hline No & Kategori & $\begin{array}{c}\text { Rentang } \\
\text { Nilai }\end{array}$ & $\begin{array}{c}\text { Jml } \\
\text { Siswa }\end{array}$ & Skor & Persen & Rata-rata \\
\hline 1 & Sangat Baik & $86-100$ & 7 & 665 & $21,91 \%$ & $\underline{2670}$ \\
2 & Baik & $81-85$ & 14 & 1136 & $43,48 \%$ & 32 \\
3 & Cukup & $75-80$ & 10 & 795 & $31,30 \%$ & $=83,44 \%$ \\
4 & Kurang & $0-74$ & 1 & 74 & $3,13 \%$ & \\
\hline \multicolumn{7}{c}{32} \\
\hline
\end{tabular}

Dari tabel 8 dapat dilihat bahwa nilai rata-rata kelas dalam aspek penggunaan bahasa dalam surat adalah 83,44 \% atau kategori baik. Dari keseluruhan siswa yang mendapat skor $86-100$ atau kategori baik sekali belum ada 7 siswa atau 21,91 \%, Kategori baik dengan rentang nilai 81 85 ada 14 siswa atau $43,48 \%$, kategori cukup dengan rentang nilai 75 - 80 ada 10 siswa atau $31,30 \%$, dan kategori kurang dengan rentang nilai $0-74$ ada 1 siswa.

Tabel 9. Hasil Tes Keterampilan Menulis Surat Pribadi Siklus I

\begin{tabular}{ccccccc}
\hline No & Kategori & $\begin{array}{c}\text { Rentang } \\
\text { Nilai }\end{array}$ & $\begin{array}{c}\text { Jml } \\
\text { Siswa }\end{array}$ & Skor & Persen & Rata-rata \\
\hline 1 & Sangat Baik & $86-100$ & 5 & 475 & $15,65 \%$ & $\underline{2648}$ \\
2 & Baik & $81-85$ & 13 & 1095 & $40,69 \%$ & 32 \\
3 & Cukup & $75-80$ & 8 & 638 & $25,04 \%$ & $=82,75 \%$ \\
4 & Kurang & $0-74$ & 6 & 440 & $6,26 \%$ & \\
\hline & & 32 & 2648 & & \\
\hline
\end{tabular}

Dari tabel 9 hasil tes keterampilan menulis surat pribadi dalam siklus I rata-rata 82,75\% atau kategori baik. Dari jumlah keseluruhan siswa yang mendapat kategori sangat baik dengan rentang nilai 86 - 100 ada 5 siswa atau 15,65\%, Kategori baik dengan rentang nilai 81 - 85 ada 13 siswa atau 40,69\%, kategori cukup dengan rentang nilai $75-80$ ada 8 siswa atau 25,04\%, dan 
kategori kurang dengan rentang nilai 0 - 74 ada 6 siswa. Pada siklus I sudah ada peningkatan dibandingkan dengan pratindakan, Namun peningkatan tersebut belum bisa mengubah dari baik menjadi sangat baik. Oleh karena itu masih perlu dilanjutkan lagi pada siklus II.

Hasil non tes terdiri dari hasil observasi, hasil jurnal siswa dan wawancara.

Hasil observasi terhadap sikap siswa selama proses pembelajaran sebagai berikut : a). Saat guru menyampaikan tujuan pembelajaran dan motivasi, semua siswa memperhatikan, tenang, dan sungguh-sungguh mengikuti pembelajaran, b). Saat guru menjelaskan tentang perbedaan surat pribadi dengan surat resmi, baik dari segi definisi, komposisi, isi dan bahasanya, siswa-siswa mendengarkan dengan baik meskipun masih ada siswa yang berbicara dengan temannya. Di samping itu mereka kelihatan masih bingung sebelum diberikan contoh (example), c). Ketika guru memberikan contoh tentang surat pribadi, ternyata siswa semakin aktif dan banyak yang meresponnya dengan berbagai pertanyaan seputar surat pribadi tersebut, d). Ketika guru memberi kesempatan kepada siswa supaya bertanya tentang hal-hal yang belum jelas, sebagian besar siswa hanya diam saja, dan e). Ketika siswa ditugasi kelompok untuk menulis surat pribadi dengan topik yang sudah ditentukan oleh guru, ternyata masih ada siswa yang masih bengong sendiri, karena kurang mungkin dia kurang konsentrasi ketika memperhatikan penjelasan cara menulis surat pribadi dengan menggunakan metode examples non examples.

Jurnal siswa memuat ungkapan perasaan siswa yang ada kaitannya dengan hal berikut ini: 1) Pengalaman belajar tentang surat pribadi, 2) Materi yang telah dipahami, 3) Materi yang belum dipahami, 4) Respon siswa dalam mengikuti pelajaran, 5) Kemudahan dan kesulitan dalam menulis surat pribadi, dan 6) Gaya guru mengajar. Materi yang disampaikan mengenai surat pribadi dengan menggunakan metode examples non examples tidak terlalu sulit dan mudah dipahami dibandingkan dengan materi sebelumnya. Ketertarikan siswa dalam menerima penjelasan guru lebih menarik dan memperhatikan meskipun masih ada yang berbicara dengan temannya. Jurnal siswa tentang kesulitan dalam menulis surat pribadi yaitu penyesuaian topik dengan isi surat, dari segi bahasa, dan membuat isi surat pribadi. Adapun gaya guru dalam mengajar, secara umum siswa mengatakan gurunya lebih semangat dibandingkan dengan pembelajaran biasanya. Namun terkadang guru dalam menerangkan terlalu cepat, kadang siswa sampai meminta untuk mengulangi lagi penjelasannya.

Wawancara dilakukan guru dengan siswa. Namun tidak semuanya siswa diwawancarai akan tetapi diambil yang nilainya paling rendah. Guru mengajukan pertanyaan kemudian siswa menjawab dengan malu-malu dan sedikit grogi. Secara umum siswa yang nilainya rendah mengatakan bahwa mereka kesulitan dalam memilih topik, membuat isi surat sesuai dengan topik yang dipilih, dan sulitnya untuk memulai menulis isi surat sesuai dengan topik yang dipilih.

Hasil tes pada siklus II ini merupakan tindak lanjut dari siklus I. Kriteria penilaian pada siklus II ini masih sama dengan siklus I yang meliputi 3 aspek penilaian, diantaranya: (1) kelengkapan komposisi surat, (2) penggunaan bahasa dalam surat, (3) kesesuaian isi dengan topik. Adapun hasilnya sebagai berikut:

Tabel 10. Hasil Tes Aspek Komposisi Surat

\begin{tabular}{ccccccc}
\hline No & Kategori & $\begin{array}{c}\text { Rentang } \\
\text { Nilai }\end{array}$ & $\begin{array}{c}\text { Jml } \\
\text { Siswa }\end{array}$ & Skor & Persen & Rata-rata \\
\hline 1 & Sangat Baik & $86-100$ & 17 & 1685 & $53,21 \%$ & $\underline{2941}$ \\
2 & Baik & $81-85$ & 12 & 1018 & $37,56 \%$ & 23 \\
3 & Cukup & $75-80$ & 3 & 238 & $9,39 \%$ & $=91,91 \%$ \\
4 & Kurang & $0-74$ & 0 & 0 & $0 \%$ & \\
\hline
\end{tabular}


Dari tabel 10 dapat dilihat bahwa nilai rata-rata kelas dalam aspek kelengkapan komposisi surat adalah 91,91 \% atau kategori sangat baik. Dari keseluruhan siswa yang mendapat skor 86 100 atau kategori baik sekali ada 17 siswa atau 53,21\%, Kategori baik dengan rentang nilai 81 85 ada 12 siswa atau 37,56\%, kategori cukup dengan rentang nilai 75 - 80 ada 3 siswa atau 9,39 $\%$, dan kategori kurang dengan rentang nilai 0 - 74 tidak ada.

Tabel 11. Hasil Tes Aspek Isi Surat

\begin{tabular}{ccccccc}
\hline No & Kategori & $\begin{array}{c}\text { Rentang } \\
\text { Nilai }\end{array}$ & $\begin{array}{c}\text { Jml } \\
\text { Siswa }\end{array}$ & Skor & Persen & Rata-rata \\
\hline 1 & Sangat Baik & $86-100$ & 22 & 2170 & $68,86 \%$ & $\underline{3011}$ \\
2 & Baik & $81-85$ & 9 & 761 & $28,17 \%$ & 32 \\
3 & Cukup & $75-80$ & 1 & 80 & $3,13 \%$ & $=94,10 \%$ \\
4 & Kurang & $0-74$ & 0 & 0 & 0 & \\
\hline
\end{tabular}

Dari tabel 11 dapat dilihat bahwa nilai rata-rata kelas dalam aspek kesesuaian isi surat dengan topik adalah 94,10\% atau kategori sangat baik. Dari keseluruhan siswa yang mendapat skor 86 - 100 atau kategori baik sekali ada 22 siswa atau 68,86 \%, Kategori baik dengan rentang nilai $81-85$ ada 9 siswa atau 28,17\%, kategori cukup dengan rentang nilai $75-80$ ada 1 siswa atau 3,13\%, dan kategori kurang dengan rentang nilai $0-74$ tidak ada.

Tabel 12. Hasil Tes Aspek Bahasa Surat

\begin{tabular}{ccccccc}
\hline No & Kategori & $\begin{array}{c}\text { Rentang } \\
\text { Nilai }\end{array}$ & $\begin{array}{c}\text { Jml } \\
\text { Siswa }\end{array}$ & Skor & Persen & Rata-rata \\
\hline 1 & Sangat Baik & $86-100$ & 30 & 2930 & $93,90 \%$ & $\underline{3100}$ \\
2 & Baik & $81-85$ & 2 & 170 & $6,26 \%$ & 32 \\
3 & Cukup & $75-80$ & 0 & 0 & 0 & $=96,88 \%$ \\
4 & Kurang & $0-74$ & 0 & 0 & 0 & \\
\hline
\end{tabular}

Dari tabel 12 dapat dilihat bahwa nilai rata-rata kelas dalam aspek penggunaan bahasa dalam surat adalah 96,88 \% atau kategori sangat baik. Dari keseluruhan siswa yang mendapat skor 86 - 100 atau kategori baik sekali ada 30 siswa atau 93,90\%, Kategori baik dengan rentang nilai 81 - 85 ada 2 siswa atau 6,26\%, kategori cukup dengan rentang nilai 75 - 80 tidak ada, dan kategori kurang dengan rentang nilai $0-74$ tidak ada.

Tabel 13. Hasil Tes Keterampilan Menulis Surat Pribadi Siklus II

\begin{tabular}{ccccccc}
\hline No & Kategori & $\begin{array}{c}\text { Rentang } \\
\text { Nilai }\end{array}$ & $\begin{array}{c}\text { Jml } \\
\text { Siswa }\end{array}$ & Skor & Persen & Rata-rata \\
\hline 1 & Sangat Baik & $86-100$ & 31 & 3041 & $97,03 \%$ & $\frac{3126}{32}$ \\
2 & Baik & $81-85$ & 1 & 85 & $3,13 \%$ & 0 \\
3 & Cukup & $75-80$ & 0 & 0 & 0 & $=97,69 \%$ \\
4 & Kurang & $0-74$ & 0 & 0 & 0 & \\
\hline
\end{tabular}

Dari tabel 13 dapat dilihat bahwa nilai rata-rata kelas dalam keterampilan menulis surat pribadi dalam siklus II adalah 97,69 \% atau kategori sangat baik. Dari keseluruhan siswa yang mendapat skor 86 - 100 atau kategori sangat baik ada 31 siswa atau 97,03\%, Kategori baik dengan rentang nilai 81 - 85 ada 1 siswa atau 3,13\%, kategori cukup dengan rentang nilai 75 - 80 tidak ada, dan kategori kurang dengan rentang nilai $0-74$ tidak ada.

Dari tabel 13 hasil tes keterampilan menulis surat pribadi pada siklus II dapat dilihat bahwa kategori kurang dengan rentang $0-74$ sudah tidak ada, kategori cukup dengan rentang nilai 75 - 
80 juga tidak ada, kategori baik dengan rentang nilai 81 - 85 hanya ada 1 siswa atau 3,13\%, bahkan kategori sangat baik dengan rentang nilai 86-100 dapat dicapai sampai dengan 31 siswa atau $97,03 \%$.

Berdasarkan hasil tes yang telah dilaksanakan bahwa nilai rata-rata pada siklus II mencapai 97,69 \%. Hasil tersebut jika dibandingkan dengan hasil penelitian siklus I, tampak peningkatan. Hasil penelitian tes siklus I hanya mencapai $82,75 \%$ dengan kategori baik atau dengan kata lain mengalami peningkatan sebesar $14,94 \%$.

Hasil non tes mencakup hasil observasi (pengamatan), hasil jurnal siswa, dan wawancara.

\section{Hasil Observasi}

Proses pembelajaran dari awal sampai akhir, siswa kelihatan antusias dan mulai mendalami tentang materi yang disampaikan. Dibuktikan banyak siswa yang bertanya dan mereka ingin mengetahui lebih lanjut agar benar-benar paham.

Praktik dalam penulisan surat pribadi dengan metode examples non examples pada siklus II ini siswa lebih bersemangat dalam melaksanakan dan menuangkan hasilnya berupa surat pribadi. Bahkan ada yang menulis dua surat pribadi dengan judul dan topik yang berbeda.

\section{Hasil Jurnal Siswa}

Siswa merasa senang dengan materi yang diberikan karena siswa sering melatih dengan mengamati objek di sekelilingnya. Siswa merasa sangat tertarik dengan metode example non example karena siswa merasa lebih gampang dengan diberikannya contoh-contoh sehingga siswa akan lebih gampang dalam menuangkan ide dan gagasannya untuk dijadikan surat pribadi.

Di samping itu siswa merasa lebih mudah, karena mereka mulai membiasakan setelah melihat contoh-contoh secara langsung kemudian dituangkan dalam bentuk menulis surat pribadi. Gaya guru dalam mengajarkan pun lebih semangat, apalagi melihat siswanya yang semangat untuk memperhatikan secara langsung contoh-contoh surat pribadi, mungkin karena hal tersebut sangat berhubungan dengan kehidupan sehari-hari.

\section{Hasil Wawancara}

Wawancara dilakukan oleh guru dengan mengajukan beberapa pertanyaan kepada siswa. Siswa dalam menjawab pertanyaan mulai akrab dan tidak grogi lagi, karena siswa sudah terbiasa aktif ketika mengajukan pertanyaan atau menjawab pertanyaan mengenai materi ketika proses belajar mengajar.

Pendapat siswa mengenai pembelajaran menulis surat pribadi dengan menggunakan metode example non example lebih mudah karena siswa merasa mudah dalam mencari inspirasi, dengan melihat contoh-contoh yang diberikan oleh guru kemudian dituangkan dalam bentuk surat pribadi. Topik-topik yang diberikan oleh guru juga sangat mudah dan berhubungan dengan kehidupan sehari-hari sehingga mereka bisa bertukar pikiran dengan temannya ketika bekerja kelompok, ketika melihat topik yang menarik tersebut kemudian dipraktekkan untuk menulis surat pribadi. Bahkan siswa ada yang meminta agar pembelajaran menulis surat pribadi ini dilakukan lagi setelah siklus II. Sampai dengan selesai pembelajaran siswa tidak ada yang mengungkapkan kesulitan dalam pembelajaran tersebut. Hal ini terbukti dengan hasil tes yang mengalami peningkatan.

\subsection{Pembahasan}

Tabel 14. Hasil Peningkatan Menulis Surat Pribadi Pada Pratindakan ke Siklus I

\begin{tabular}{ccccc}
\hline \multirow{2}{*}{ No } & \multirow{2}{*}{ Aspek Penilaian } & \multicolumn{2}{c}{ Nilai Rata-Rata Kelas } & \multirow{2}{*}{ Peningkatan } \\
& & Pratindakan & Siklus I & \\
\hline 1. & Kelengkapan komposisi surat & $58,32 \%$ & $80,91 \%$ & $70,59 \%$ \\
\hline
\end{tabular}




\begin{tabular}{lllll}
\hline 2. & Kesesuaian isi surat dengan & $56,16 \%$ & $82,57 \%$ & $80,12 \%$ \\
topik & & $44,38 \%$ & $83,44 \%$ & $81,51 \%$ \\
3. & Penggunaan bahasa dalam surat & $44 \%$
\end{tabular}

Data awal pada pratindakan menunjukkan bahwa sebagian besar kemampuan siswa dalam menulis surat pribadi masih rendah. Masalah tersebut dikuatkan dengan hasil tes pratindakan dengan rata nilai $48,75 \%$ dan termasuk kategori kurang. Kemampuan siswa pada setiap aspek masih rendah yakni dalam aspek kelengkapan komposisi surat, penggunaan bahasa dalam surat, dan kesesuaian isi surat dengan topik yang ditentukan oleh guru. Hal tersebut dapat dilihat hasilnya bahwa nilai rata-rata siswa dalam aspek kelengkapan komposisi surat 58,32. Aspek kesesuaian isi surat dengan topik yang ditentukan oleh guru nilai rata-rata siswa 56,16. Aspek penggunaan bahasa dalam surat nilai rata-rata siswa 44,38. Melihat keadaan tersebut, peneliti mencoba mengatasinya dengan teknik examples non examples. Dengan teknik tersebut secara langsung suasana proses pembelajaran pada siklus I tampak lebih semangat dibandingkan dengan kondisi awal dan hasilnya pun menunjukkan adanya peningkatan. Berdasarkan tabel 1 pada siklus I nilai rata-rata kelas pada aspek kelengkapan komposisi surat yang awalnya 61,30 menjadi 80,91 atau mengalami peningkatan $70,59 \% \%$. Aspek kesesuaian isi surat dengan topik yang awalnya 56,16 menjadi 82,57 atau mengalami peningkatan $80,12 \%$ Aspek penggunaan bahasa dalam surat yang awalnya 44,38 menjadi 83,44 atau mengalami peningkatan $81,51 \%$ Begitupun berikutnya di siklus II terjadi adanya peningkatan daripada siklus I. Adapun hasilnya dapat dilihat pada tabel berikut ini.

Tabel 15. Hasil Peningkatan Menulis Surat Pribadi Pada Siklus I dan Siklus II

\begin{tabular}{|c|c|c|c|c|}
\hline \multirow{2}{*}{ No } & \multirow{2}{*}{ Aspek Penilaian } & \multicolumn{2}{|c|}{ Nilai Rata-Rata Kelas } & \multirow{2}{*}{ Peningkatan } \\
\hline & & Siklus I & Siklus II & \\
\hline 1. & Kelengkapan komposisi surat & $80,91 \%$ & $91,91 \%$ & $88,39 \%$ \\
\hline 2. & $\begin{array}{l}\text { Kesesuaian isi surat dengan } \\
\text { topik }\end{array}$ & $82,57 \%$ & $94,10 \%$ & $90,51 \%$ \\
\hline 3. & Penggunaan bahasa dalam surat & $83,44 \%$ & $96,88 \%$ & $94,27 \%$ \\
\hline
\end{tabular}
surat yang awalnya 80,91 menjadi 91,91 atau mengalami peningkatan 88,39\% Aspek kesesuaian isi surat dengan topik yang awalnya 82,57 menjadi 94,10 atau mengalami peningkatan $90,51 \%$. Aspek penggunaan bahasa dalam surat yang awalnya 83,44 menjadi 96,88 atau mengalami peningkatan $94,27 \%$.

Hal tersebut ternyata terbukti respon siswa dalam mengikuti pembelajaran lebih antusias dan hasilnya pun sangat menggembirakan jika dibandingkan dengan hasil tes pada siklus I, yaitu yang awalnya 82,75 atau kategori baik, sedangkan nilai rata-rata pada siklus II 97,69 atau kategori sangat baik. Jadi mengalami peningkatan $95,10 \%$

Dari hasil wawancara siswa mengatakan bahwa dengan menggunakan metode examples non examples merasa lebih mudah dalam menulis surat pribadi, karena langsung memperhatikan contoh-contoh dari surat pribadi, bahkan dari hasil wawancara tersebut siswa ingin pembelajaran seperti itu dilaksanakan lagi. Berdasarkan hasil yang demikian peneliti merasa tidak perlu melanjutkan tindakan setelah siklus II, karena hasilnya sudah menunjukkan peningkatan yang cukup tajam.

Penjelasan tersebut menunjukkan bahwa salah satu metode yang secara teoritis maupun praktis dapat meningkatkan keterampilan siswa kelas VII A SMP Negeri 9 Kota Sorong dalam menulis surat pribadi adalah dengan menggunakan metode examples non examples.

Berdasarkan penjelasan di atas, bisa penulis simpulkan hasil peningkatan rata-rata nilai mulai dari pratindakan, siklus I, dan siklus II dengan grafik di bawah ini: 


\section{Grafik 1. Peningkatan Nilai Rata-Rata Menulis Surat Pribadi Dari Pratindakan, Siklus I dan Siklus II}

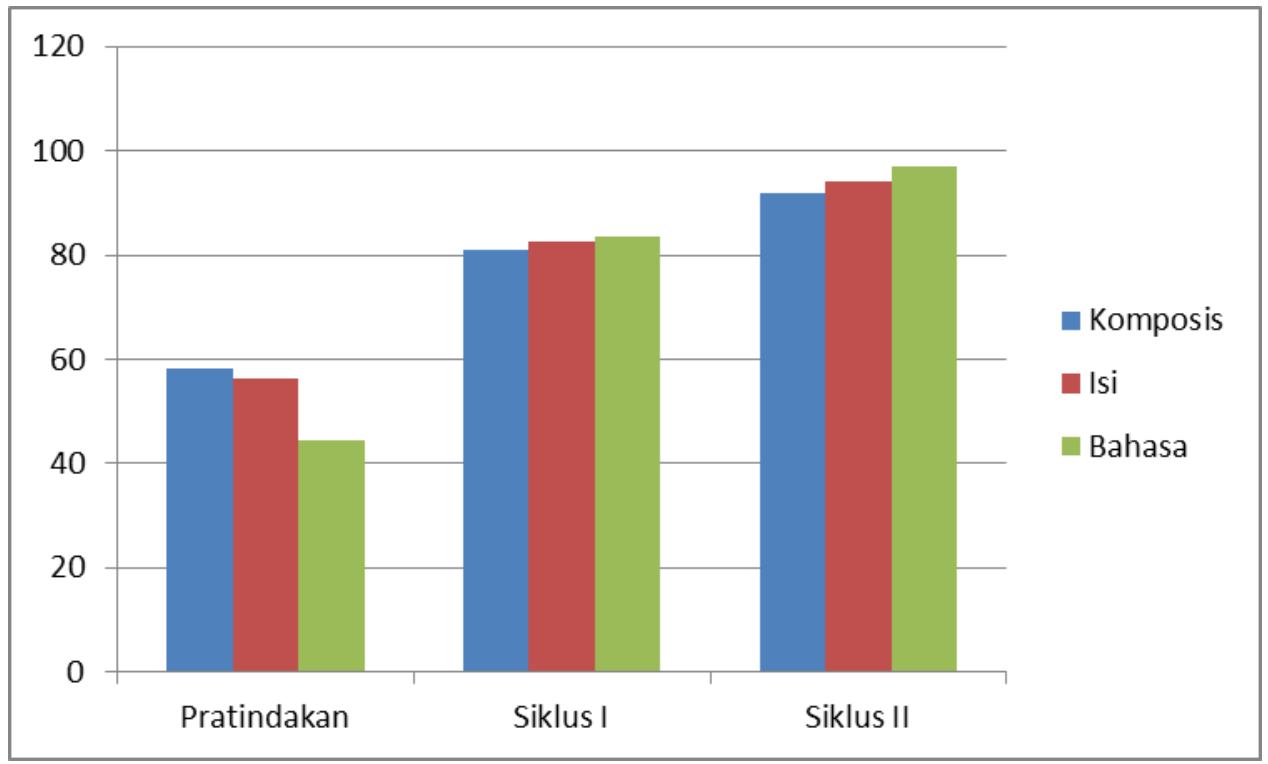

Berdasarkan grafik di atas bisa disimpulkan bahwa peningkatan rata-rata nilai dari pratindakan ke siklus I dan ke siklus II, peningkatan nilainya sangat baik. Berdasarkan grafik di atas bisa dilihat peningkatan nilai rata-rata dari pra tindakan ke siklus I, pada aspek kelengkapan komposisi surat yang awalnya 58.32 menjadi 80,91 atau mengalami peningkatan 70,59\% Aspek kesesuaian isi surat dengan topik yang awalnya 56,16 menjadi 82,57 atau mengalami peningkatan $80,12 \%$. Aspek penggunaan bahasa dalam surat yang awalnya 44,38 menjadi 83,44 atau mengalami peningkatan $81,51 \%$. Berdasarkan grafik di atas, juga bisa dilihat peningkatan nilai rata-rata dari siklus I ke siklus II, pada aspek kelengkapan komposisi surat yang awalnya 80,91 menjadi 91,91 atau mengalami peningkatan 88,39 \%. Aspek kesesuaian isi surat dengan topik yang awalnya 82,57 menjadi 94,10 atau mengalami peningkatan $90,51 \%$. Aspek penggunaan bahasa dalam surat yang awalnya 83,44 menjadi 96,88 atau mengalami peningkatan $94,27 \%$. Jadi bisa disimpulkan dari data di atas, bahwa pembelajaran menulis surat pribadi dengan menggunakan model examples non examples sangat berhasil dengan peningkatan nilai yang sangat baik sekali. Bisa dilihat bahwa nilai siswa dari pratindakan ke siklus I mengalami peningkatan, begitu juga dari siklus I ke siklus II, juga mengalami peningkatan yang sangat baik

\section{Kesimpulan dan Implikasi}

\subsection{Kesimpulan}

Berdasarkan penelitian dan pembahasan pada bab sebelumnya dapat disimpulkan bahwa: 1). Teknik pengamatan objek secara langsung, kemampuan siswa kelas VII A SMP Negeri 9 Kota Sorong dalam menulis surat pribadi dapat ditingkatkan. Peningkatan tersebut sungguh memuaskan. Hal ini terbukti pada hasil tes setelah tindakan. Pada tahap pratindakan nilai rata-rata siswa hanya $48,75 \%$ atau kategori kurang, kemudian pada tindakan siklus I nilai rata-rata yang diperoleh 82,75 $\%$ atau kategori baik, artinya mengalami peningkatkan sebesar 81,22\% Kemudian pada siklus II nilai rata-rata siswa meningkat lebih baik lagi daripada siklus I, yaitu menjadi 97,69 \%, Dengan kata lain mengalami peningkatan sebesar $95,10 \%$ bila dibandingkan dengan hasil sebelumnya 
(siklus I), 2). Hasil penelitian non tes melalui pengamatan, wawancara, dan jurnal siswa juga menunjukkan perubahan yang positif, siswa lebih tertarik dan antusias dalam pembelajaran menulis puisi dengan menggunakan metode examples non examples, sehingga siswa mudah dalam menulis surat pribadi. Hal itu terbukti adanya permintaan beberapa siswa agar mengulangi metode pembelajaran yang sudah dilaksanakan, karena begitu antusiasnya, dan aktifnya siswa ketika menggunakan metode tersebut, sehingga siswa meminta mengulangi kembali pembelajaran dengan menggunakan metode examples non examples, dan 3). Dengan melihat tingginya angka peningkatan dan respon siswa tersebut, berarti metode examples non examples sangat cocok diterapkan dalam setiap pembelajaran.

\section{2 . Implikasi}

Melihat hasil penelitian tindakan kelas dengan judul "Peningkatan Keterampilan Menulis Surat Pribadi dengan Menggunakan Model Examples Non Examples pada Siswa Kelas VII A SMP Negeri 9 Kota Sorong Tahun Pelajaran 2016/2017" yang dilakukan ini, disarankan:1). Guru dapat mengaplikasikan 'Model Examples Non Examples' dalam pembelajaran bahasa Indonesia di sekolah/di kelas, khususnya pembelajaran menulis surat pribadi, 2). Guru dapat melakukan penelitian tindakan untuk mata pelajaran yang lain dengan penerapan model 'Model Examples Non Examples' ini agar efektivitas dan efisiensi 'Model Examples Non Examples' lebih signifikan dan representatif dalam pembelajaran, 3). Lembaga /sekolah agar memberikan keleluasaan dan mendukung sepenuhnya baik moril ataupun materiil kepada guru dalam menciptakan/menerapkan model pembelajaran yang inovatif dan menyenangkan, 4). Guru hendaknya membimbing siswa dalam menulis surat pribadi dengan metode examples non examples, 5). Topik yang dipilih dalam menulis surat pribadi hendaknya yang berhubungan dengan kehidupan sehari-hari, dan 6). Untuk mendukung hasil penelitian ini, perlu diadakan penelitian yang lain lagi tentang Model Examples Non Examples

\section{Daftar Pustaka}

Byrne, Dom. 1988. Teaching Writing Skill. London dan New York: Longman.esia. Jakarta:IKAPI.

Depdiknas. 2003. Kurikulum 2004 Sekolah Menengah Pertama Mata Pelajaran Bahasa

\section{Indonesia}

Http: karya-ilmiah.um.ac.id/indeks.php/KSDP/article/view/6063.

Http:// KlikBelajar.com/gurupkn.wordpress.com/10/11/2007/.

Http:// model-examples-non-examples/gurupkn.wordpress.com/10/11/2007/.

Lado, Robert.1964. Language Teaching. Amerika: MC Grow Hill.

Liang Gie, The. 2002. Terampil Mengarang. Yogyakarta: Andi.

Sapari, Nia Kurniati. 2008. Kompetensi Bebahasa Indonesia SMP dan MTs kelas VII. Jakarta: Pusat Perbukuan Departemen Pendidikan Nasional.

Slavin, Robert E. 2008. Cooperative Learning: Teori, Riset dan Praktik.Terjemahan Nurulita Yusron. Bandung: Nusa Media.

Sundusilah, Suci. 2005. Meningkatkan Keterampilan Menulis Surat (Korespondensi)siswa Kelas IV SDN Cimareme II Kabupaten Bandung dengan Pendekatan Multiple Intelegences Howard Gardner. Skripsi.

Syamsudin, S.2005. Dasar-Dasar Teori Sastra.Semarang: Rumah Indonesia.

Tarigan, Djago. 1990. Materi Pokok Pendidikan Bahasa Indonesia: Modul 1-6. Jakarta: Depdikbud. 
Jurnal Pendidikan, Vol. 7, No. 2, Julii 2019

ISSN: 2337-7607 e-ISSN: 2337-7593

Tarigan, Djago. Dan H.G. Tarigan. 1986. Teknik Pengajaran Keterampilan Berbahasa. Bandung: CV Angkasa. 